\title{
Acute respiratory depression as a complication of nebulised morphine
}

Eric Lang MD, Robert Jedeikin MBCHB FFA

Purpose: To present a case of respiratory depression following the administration of nebulised morphine.

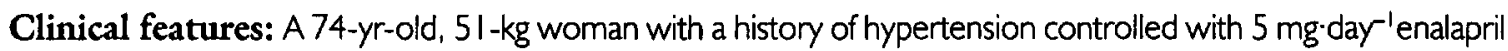
and $50 \mathrm{mg} \cdot \mathrm{day}^{-1}$ atenolol was admitted for evaluation of low back pain, loss of appetite, and weight loss. Investigation revealed advanced metastatic disease with a probable primary in the right lung. The patient's pain was well controlled with $10 \mathrm{mg}$ continuous release morphine po three times daily, and $10 \mathrm{mg}$ immediate release morphine po for breakthrough pain as required. During the two weeks following the commencement of this treatment she occasionally complained of shortness of breath. Examination revealed a fully conscious patient with slight dyspnoea and mild wheezing which responded to oxygen $30 \%$ and nebulised bronchodilators.

An oncological consultation recommended $4 \mathrm{mg}$ nebulised morphine and $4 \mathrm{mg}$ dexamethasone in saline as treatment for the bouts of breathlessness. Approximately $15 \mathrm{~min}$ after the first administration of nebulised morphine the patient became markedly bradypneic (respiratory rate: $4-5 \mathrm{bpm}$ ), hypotensive (BP $70 / 40 \mathrm{mmHg}$ ), and responded only partially to command. The pupils were pinpoint. The trachea was immediately intubated and the lungs ventilated with oxygen $40 \%$ for four hours. Following this occurrence of respiratory depression nebulised morphine was discontinued and no further events occurred.

Conclusion: Patients receiving inhaled morphine should be closely monitored and resuscitation equipment should be readily available.

Objectif : Présenter un cas de dépression respiratoire consécutive à l'administration de morphine par nébulisation. Éléments cliniques : Une patiente de 74 ans pesant $51 \mathrm{~kg}$, hypertendue contrôlée sous enalapril $5 \mathrm{mg}^{-1} \mathrm{j}^{-1}$ aténolol $50 \mathrm{mg}^{-1} \mathrm{j}^{-1}$ était admise pour l'évaluation d'une lombalgie, d'une perte d'appétit et de poids. L'investigation révélait la présence d'un cancer métastastique avancé originaire du poumon droit. La douleur était bien contrôlée avec de la morphine $10 \mathrm{mg}$ à libération continuelle po trois fois par jour et $10 \mathrm{mg}$ de morphine à libération immédiate po pour les douleurs rebelles au besoin. Pendant les deux semaines qui ont suivi le début du traitement, la patiente s'est plainte de dyspnée occasionnelle. L'examen a révélé une patiente complètement consciente avec de la dyspnée et du wheezing léger répondant favorablement à l'oxygène $30 \%$ et aux bronchodilatateurs en nébulisation. Pour traiter les attaques de dyspnée, une consultation en oncologie recommandait $4 \mathrm{mg}$ de morphine en nébulisation et $4 \mathrm{mg}$ de dexaméthazone dans du sol. phys. Quinze minutes après la première nébulisation de morphine, la patiente est devenue considérablement bradypnéique (fréquence respiratoire : 4-5 $\mathrm{r} \cdot \mathrm{min}^{-1}$ ), hypotendue (TA $70 / 40 \mathrm{mmHg}$ ) et ne répondait que partiellement aux ordres. Les pupilles étaient en myosis très serré. La trachée a été intubée immédiatement et les poumons ventilés avec de l'oxygène $40 \%$ pendant quatre heures. Après cet incident, la nébulisation de morphine a été cessée et on n'a pas observé de récidive du même type.

Conclusion : Les patients recevant de la morphine en inhalation doivent être surveillés de près et le matériel de réanimation doit être gardé à portée de main.

From the Department of Anesthesiology and Critical Care Medicine Meir Hospital, Kfar Saba, Israel. Affiliated with the Sackler School of Medicine, Tel-Aviv University, Tel-Aviv, Israel.

Address correspondence to: Eric Lang MD, Beeri 41, Tel Aviv, Israel, 64233 Israel. Fax: 972-3-6951837; E-mail: elang@bgumail.bgu.ac.il.

Accepted for publication October 3, 1997. 


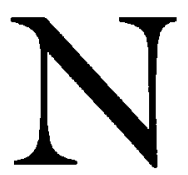

EBULISED morphine has been reported to increase exercise endurance in patients with chronic lung disease and to relieve dyspnoea in patients with cancer. ${ }^{1-3}$ The mechanism through which nebulised morphine functions is controversial. It has been postulated that the aerosol acts on peripheral opioid receptors in the lung or possibly through systemic absorption. The efficacy of nebulised morphine is controversial: other investigators have found no beneficial improvement in exercise tolerance in patients with chronic obstructive lung disease, ${ }^{4}$ or interstitial lung disease. ${ }^{5}$

We describe a patient who developed acute respiratory depression as a result of the administration of nebulised morphine.

\section{Case history}

A 74-yr-old, 51 -kg woman, with a history of hypertension, that was controlled with $5 \mathrm{mg} \cdot \mathrm{day}^{-1}$ enalapril and $50 \mathrm{mg} \cdot \mathrm{day}^{-1}$ atenolol, was admitted for evaluation of low back pain, loss of appetite, and weight loss. Chest X-ray revealed a lesion in the upper right lung. Evaluation of the patient by CT and TC99M bone scan demonstrated multiple metastatic lesions of the spine at: $\mathrm{C} 6-7, \mathrm{Tl}-2$, T8, Tl1, and LI-L3. In addition, the patient had metastatic lesions in ribs \# 1-6 on the right side. A diagnosis of metastatic disease with a probable primary in the lung was made.

The patient's pain was well controlled with $10 \mathrm{mg}$ continuous release morphine po three times daily, and $10 \mathrm{mg}$ immediate release morphine po for breakthrough pain as required. During the two weeks following the commencement of this treatment the patient occasionally complained of shortness of breath. Examination revealed a fully conscious patient with slight dyspnoea and mild wheezing which responded to oxygen 30\% and nebulised bronchodilators. An oncological consultation recommended administration of $4 \mathrm{mg}$ nebulised morphine and $4 \mathrm{mg}$ dexamethasone in saline as treatment for the bouts of breathlessness.

Approximately $15 \mathrm{~min}$ after the first administration of nebulised morphine the patient became markedly bradypneic and responded only partially to command. The blood pressure was $70 / 40 \mathrm{mmHg}$. Physical examination revealed a respiratory rate of $4-5 \mathrm{bpm}$, very poor respiratory effort and minimal wheezing over both lung fields. The pupils were pinpoint. The diagnosis of acute respiratory depression was made. The trachea was immediately intubated and the lungs ventilated with oxygen $40 \%$. Four hours later the patient had regained consciousness, arterial blood gas analyses revealed: $\left(\mathrm{F}_{1} \mathrm{O}_{2}-0.4\right) \mathrm{SaO}_{2}-99.8 \%, \mathrm{pH}-7.47, \mathrm{PO}_{2}-210 \mathrm{mmHg}$, $\mathrm{PCO}_{2}-33 \mathrm{mmHg}$. Extubation of the trachea which was easy and uneventful was performed.
Following this episode of respiratory depression treatment with nebulised morphine was discontinued and no further events occurred. Several days later the patient was transferred to hospice.

\section{Discussion}

Nebulised morphine has been reported to be useful and safe in the treatment of breathlessness in patients with chronic lung disease and cancer. ${ }^{1-3}$ Other reports have found no beneficial improvement in exercise tolerance in patients with chronic obstructive lung disease, ${ }^{4}$ or interstitial lung disease. ${ }^{5}$

The mechanism through which nebulised morphine exerts its effect is controversial. It has been postulated that the aerosol acts on peripheral opioid receptors in the lung or possibly through systemic absorption. Chrubasik et al. found systemic uptake of inhaled morphine to be extremely variable (9-35\%), however, only seven patients were examined and none had chronic lung disease. ${ }^{6}$ Cabot $e t$ al. reported that binding affinities for morphine and naloxone were two orders of magnitude lower in the lungs than those found in the brain, however, opioid binding site densities were up to 100 times greater than those in the brain. ${ }^{7}$ A recent investigation employing isolated strips of bovine trachealis muscle showed that stimulation of opioid receptors in the airways can modulate cholinergic neurotransmission and thereby reduce bronchoconstriction. ${ }^{8}$

In contrast, a study performed in healthy men failed to demonstrate that intrapulmonary opioid receptors modulated the sensation of breathlessness during exercise. ${ }^{9}$ The possibility that inhaled morphine may effect breathlessness caused by other factors, such as disease, could not be excluded. Two recent double blind studies examined the effects of nebulised morphine in men with chronic obstructive pulmonary disease (COPD). Masood et al. ${ }^{10}$ compared the effects of nebulised morphine (10 and $25 \mathrm{mg}$ ), and intravenous morphine (1 and $2.5 \mathrm{mg}$ ), with a placebo on breathlessness (visual analogue scale ventilation, gas exchange, and exercise endurance were measured during graded bicycle exercise). However, there is no certainty that the nebulised and intravenous morphine doses were equipotent. Furthermore, none of the treatments altered breathlessness, ventilation, or gas exchange at rest or at any time during exercise, and exercise endurance was unaffected. In the second study, the effect of 5 mg nebulised morphine $(5 \mathrm{ml})$ on both exercise induced breathlessness and maximum achievable power output was compared to a control group using isotonic saline as a control. There was no difference in maximum power output achieved, minute ventilation at maximum power output, nor the degree of breathlessness at maximum power 
output between the groups treated with morphine and placebo. ${ }^{11}$

This is the first report of respiratory depression as a result of the use of nebulised morphine to treat breathlessness. Naloxone was not used during the acute event because it was thought that the possible systemic side effects of naloxone (i.e., pulmonary oedema, cardiac instability, etc.) might pose a threat to the parient's life. It could be a argued that since naloxone was not administered we do not have proof that the nebulised morphine was the cause of the patient's respiratory depression. However, the proximity of the acute event to the time of administration of the morphine aerosol, the rapid recovery and reversal of the symptoms, the lack of administration of other medications that might cause respiratory depression and the one time nature of the event support nebulised morphine as the cause.

The only other medication administered to the patient was dexamethasone. A literature review does not reveal any reports of dexamethasone as a cause of respiratory depression. In that inhaled steroids are frequently used in patient care it is unlikely that this could have been the cause of the respiratory depression.

One possible reason for the occurrence of marked respiratory depression in this patient may be the additive effect of the nebulised morphine and the slow release morphine. This, despite the low dose of slow release morphine being administered. The systemic uptake of nebulised morphine in patients with lung metastases has not been investigated. It is possible that it is greater than in otherwise healthy patients due to disruption of the normal tissue structure.

Based on this experience, it is prudent that patients receiving inhaled morphine should be closely monitored and that resuscitation equipment be readily available. Further controlled studies should be performed to determine if the administration of nebulised morphine is justified given the potential risks.

\section{References}

1 Farncombe M, Chater S. Clinical application of nebulized opioids for treatment of dyspnoea in patients with malignant disease. Support Care Cancer 1994; 2: 184-7.

2 Farncombe $M$, Chater S, Gillin A. The use of nebulized opioids for breathlessness: a chart review. Palliat Med 1994; 8: 306-12.

3 Farncombe $M$, Chater $S$. Case studies outlining use of nebulized morphine for patients with end-stage chronic lung and cardiac disease. J Pain Symptom Manage 1993; 8: 221-5.

4 Beauford W, Saylor TT, Stansbury DW, Avalos K, Light $R W$. Effects of nebulized morphine sulfate on the exer- cise tolerance of the ventilatory limited COPD patient. Chest 1993; 104: 175-8.

5 Harris-Eze AO, Sridhar G, Clemens RE, Zintel TA, Gallagher CG, Marciniuk DD. Low-dose nebulized morphine does not improve exercise in interstitial lung disease. Am J Respir Crit Care Med 1995; 152: 1940-5.

6 Chrubasik J, Wiust H, Friedrich G, Geller E. Absorption and bioavailability of nebulized morphine. Br J Anesth 1988; 61: 228-30.

7 Cabot PJ, Dodd PR, Cramond T, Smith MT. Characterization of non-conventional opioid binding sites in rat and human lung. Eur J Pharmacol 1994; 268: 247-55.

8 Zappi L, Nicosia F, Rocchi D, Song P, Rehder K. Opioid agonists modulate release of neurotransmitters in bovine trachealis muscle. Anesthesiology 1995; 83: 543-51.

9 Masood AR, Subban MMF, Reed JW, Thomas SHL. Effects of inhaled nebulized morphine on ventilation and breathlessness during exercise in healthy man. Clin Sci (Colch) 1995; 88: 447-52.

10 Masood AR, Reed JW, Thomas SHL. Lack of effect of inhaled morphine on exercise-induced breathlessness in chronic obstructive pulmonary disease. Thorax 1995; 50: 629-34.

11 Leung R, Hill P, Burdon J. Effect of inhaled morphine on the development of breathlessness during exercise in patients with chronic lung disease. Thorax 1996; 51 : 596-600. 